\title{
The comparison of the divergent and convergent tectonic plates margins seismicity - the case study: Red Sea and Zagros
}

\author{
Ali AMJADI ${ }^{1}$, Bahram AKASHE ${ }^{1, *}$ (D), Mohammad ARIAMANESH ${ }^{2}$, \\ Mohsen POURKERMANI ${ }^{3}$ \\ ${ }^{1}$ Department of Geophysics, North Tehran Branch, Islamic Azad University, Tehran, Iran \\ ${ }^{2}$ Department of Geology, Payam Noor University, Tehran, Iran \\ ${ }^{3}$ Department of Geology, North Tehran Branch, Islamic Azad University, Tehran, Iran
}

\begin{abstract}
Regarding the seismicity of the Zagros and the Red Sea regions, the present study has investigated and analyzed the seismicity with $M \geq 5$ of these regions with obtaining seismicity coefficients, geometrical characteristics including depth, earthquake dispersion and focal mechanism of earthquakes, and their relation to each other. The estimated b-value for these two zones is approximately the same, being equal to $\sim 1.2$. However, the total number of earthquakes in the Zagros is much higher (approximately 5.5 times), when the ratio of small to large earthquakes is about the same amount. In this study, focal depth of more earthquakes occurred and located in the Zagros and Red Sea respectively in depth of $15-20 \mathrm{~km}$ and $10-15 \mathrm{~km}$ from the earth surface, indicating that the Zagros Crust is thicker than the Red Sea.
\end{abstract}

Key words: Zagros, Red Sea, focal depth, magnitude-frequency relation, focal mechanism

\section{Introduction}

The Iranian plateau is a large part of the Alpine-Himalayan orogenic belt between the two Arabian Precambrian and the Hercynian Eurasian persistent zones with a convergence rate of 25 to $30 \mathrm{~mm}$ per year in the north-south direction (DeMets et al., 1994). The convergence of the Arabian plateau and the Central Iranian microcontinent is accompanied by numerous folds and fault systems called the Zagros fold-thrust belt. The present-day convergence between Arabia and Eurasia is $2-3 \mathrm{~cm} / \mathrm{yr}$ (Vernant et al., 2004) in the $\mathrm{N}-\mathrm{S}$ direction and is assumed to be unchanged since at least $10 \mathrm{Ma}$

\footnotetext{
* corresponding author: e-mail: akashebahram@gmail.com
} 
(McQuarrie et al., 2003). The Zagros Mountain belt, which trends NW-SE, extends over $1800 \mathrm{~km}$ from southeastern Turkey and north of Iraq border in the NW and W of Iran to the Makran area in the SE, where oceanic subduction is still active (Smith et al., 2012). This belt is the result of the collision between the Arabian shield and the Iranian Block in the late Miocene (Stöcklin, 1974) and is currently close to half the rate of convergence between the two plates (Tatar et al., 2002; Vernant et al., 2004; Engdahl et al., 2006). Also, it includes more than $50 \%$ of the recorded earthquakes in the Iranian territory (Mirzaei et al., 1998). The thickness of the sedimentary cover and the basement depth in the area are estimated to be between 10 and $12 \mathrm{~km}$ (Berberian, 1995) and $45 \mathrm{~km}$, respectively (Hatzfeld et al., 2003; Paul et al., 2010). Most of the earthquakes located in the simply folded belt of Zagros have thrust mechanisms and depths of less than $\sim 20 \mathrm{~km}$. Furthermore, their ruptures have rarely reached the surface, which may be due to the presence of salt layers in the sedimentary cover (Jackson and Fitch, 1981; Talebian and Jackson, 2004).

The Red Sea, known as Bahr al Ahmar in Arabic, is a semi-enclosed, elongated warm body of water about $2,000 \mathrm{~km}$ long with a maximum width of $355 \mathrm{~km}$, a surface area of roughly $458,620 \mathrm{~km}^{2}$, and a volume of $250,000 \mathrm{~km}^{3}$ (Head, 1987). The Red Sea is one of the youngest oceanic zones of the Earth and was created by slow seafloor spreading. The southeastern and southwestern border of the Arabian plateau with Africa is the diverging oceanic boundary, covered by the Gulf of Aden and the Red Sea, respectively. The plate is bounded by the Bitlis Suture and the Zagros fold belt and subduction zone to the north and north-east, and the Gulf of Aden spreading centre and Owen Fracture Zone to the south and southeast (modified after Stern and Johnson, 2010). The Red Sea was formed by extensional rupturing of the Precambrian lithosphere beginning in the Late Oligocene. The sea floor spreading began about $5 \mathrm{Ma}$ in the southern Red Sea (Roeser, 1975), and the transition from continental to oceanic rifting is occurring currently in the Central and Northern Red Sea (Cochran and Martinez, 1988; Guennoc et al., 1990; Cochran et al., 1991). This recent seismic activity indicates that some Cenozoic faults in the Red Sea coastal plain are seismically active. Together with the Gulf of Aqaba-Dead Sea transform fault, it forms the western boundary of the Arabian plate, which is moving in a north-east direction. The Dead Sea fault system is located along the northwestern 
boundary of the plate. The fault is left lateral with a minor component of rotation that results in the development of pull-apart basins, such as the Dead Sea rift basin (Garfunkel, 1981).

\section{Geologic and tectonic setting of the Zagros}

The Zagros mountain belt results from the closure of the Neotethys oceanic domain and the collision of the northern margin of the Arabian platform with the microplates of central Iran, accreted to the southern margin of Eurasia during the Mesozoic (e.g. Besse et al., 1998). The Zagros orogenic belt is bounded to the northwest by the East Anatolian left-lateral strike-slip fault (EAF) and to the southeast by the Oman Line (OL) (Falcon, 1969), which is here considered to be a transform fault inherited from the opening of Neo-Tethys (Alavi, 2004).

The fold and thrust belt on the Arabian Plate is a result of deformation of the Zagros Orogenic Belt (ZOB) passive margin sediments that have been caused by continental collision (Alavi, 1994; Ghasemi and Talbot, 2006; Horton et al., 2008; Allahyari et al., 2010; Saccani et al., 2013).

The Zagros were traditionally classified by distinctive lithological units and structural styles into four NW trending tectonometamorphic and magmatic belts (Fig. 1). The Zagros Fold-and-Thrust Belt (ZFTB) continental collision zone is one of the youngest and most seismically active zones on Earth (Palano et al., 2018). The Zagros Folded Thrust Belt (ZFTB) is divided into: The High Zagros Thrust Belt (Zagros Imbricate Zone); the Zagros Simply Folded Belt; the Zagros Foredeep; the Zagros Coastal Plain; and the Mesopotamian-Persian Gulf foreland basin (James and Wynd, 1965; Khadivi, 2010). The ZFTB is affected by frequent earthquakes of magnitude generally smaller than 7 concentrated at a depth of $8-15 \mathrm{~km}$ in the upper crystalline crust beneath the sedimentary sequence (Paul et al., 2006; Talebian and Jackson 2004; Tatar et al., 2004). The presence of negative isostatic anomaly near the Zagros main thrust (Snyder and Barazangi, 1986) and seismic evidence with focal depths greater than $50 \mathrm{kms}$ in the ISC and USGS prove subduction of the Arabian plate beneath central Iran (Nowroozi, 1971).

Berberian (1995) described tectonic developments of this region as a platform phase in the Paleozoic, rifting in the Permian and Triassic, forming in- 


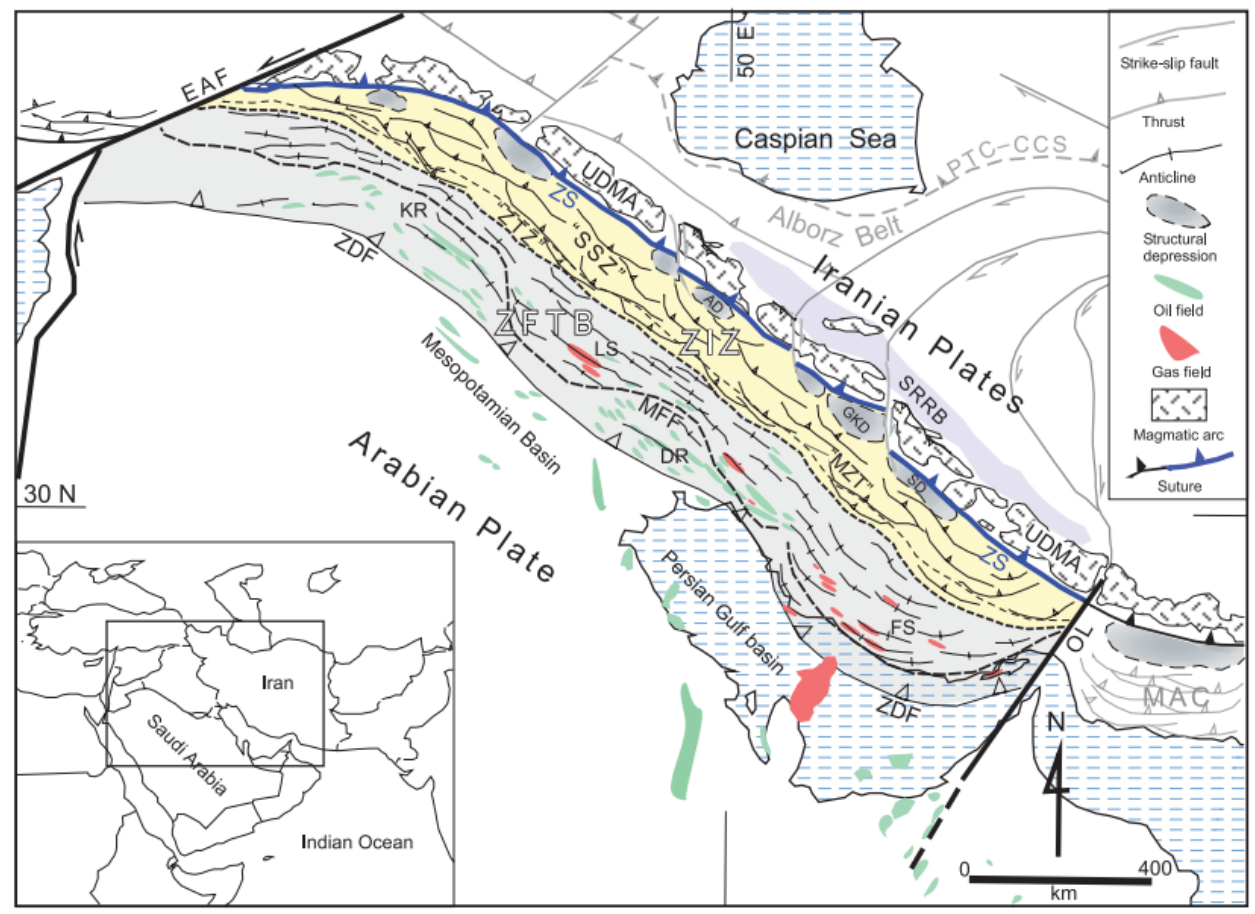

Fig. 1. Subdivisions of the Zagros orogenic belt. Abbreviations: AD - Arak depression; DR - Dezful recess; EAF - East Anatolian Fault; FS - Fars salient; GKD - Gav Khooni depression; KR - Karkuk recess; LS - Lorestan salient; MAC - Makran accretionary complex; MFF - "Mountain front flexure"; "MZT" - "Main Zagros Thrust"; OL - Oman Line; PTC-CCS - Paleo-Tethyan continent-continent collisional suture; SD - Sirjan depression; SRRB - Saveh-Rafsanjan retroforeland basin; "SSZ" - Sanandaj-Sirjan zone; "ZTZ" - Zagros thrust zone; UDMA - Urumieh - Dokhtar magmatic assemblage; ZDF - Zagros deformational front; ZFTB - Zagros fold-thrust belt; ZIZ - Zagros imbricate zone; ZS - Zagros suture. Hydrocarbon fields of the region, oil in green and gas in red, are shown (Alavi, 2007).

active continental margins (with seafloor spreading to the north-east) in the Jurassic and Early Cretaceous, subduction to the northeast and ophiolite and radiolite deposition in the late Cretaceous, and finally the continentalcontinental collision and shortening during the Neogene.

Today, their effects appear on or near the surface of the Earth as thrust faults. It can be said that the Zagros basement is about 25 to $50 \mathrm{~km}$ thickness (Giese et al., 1984). 
Based on Dehghani and Makris (1984), under the main Zagros fault (high Zagros), gravity anomalies reach to a minimum (-230 mgal), and in this area, the Iranian crust thickness 50 to 55 kilometers has the highest thickness, which is attributed to the compressive process associated with the opening of the Red Sea.

\section{Geologic and tectonic setting of the Red Sea}

The Red Sea, an enclosed body of water that lies between $30^{\circ} \mathrm{N}$ and $12^{\circ} 30^{\prime} \mathrm{N}$, is about $1,932 \mathrm{~km}$ long and $280 \mathrm{~km}$ in width (Morcos, 1970). The narrow southern Strait of Bab-al-Mandab (29 km in width) is the boundary between the Red Sea and the Gulf of Aden. The Red Sea is one of the youngest oceanic zones on earth and was created by slow seafloor spreading. Together with the Gulf of Aqaba-Dead Sea transform fault, it forms the western boundary of the Arabian plate, which is moving in a north-easterly direction. The plate is bounded by the Bitlis Suture and the Zagros fold belt and subduction zone to the north and north-east, and the Gulf of Aden spreading centre and Owen Fracture Zone to the south and southeast (Rasul and Stewart, 2015) (Fig. 2 modified after Stern and Johnson, 2010).

According to Swartz and Arden (1960), with the onset of Pliocene, marine sediments were deposited in the Red Sea due to the influx of water from the Indian Ocean into the Red Sea, meanwhile due to the uplift of the Suez Canal, the connection between the Mediterranean Sea and the Red Sea has been severed. The Red Sea Rift System is one of the world's largest active rift systems, which comprises a variety of rifting stages starting from initial faulting and advancing through several stages of continental rifting. It began about 30 million years ago, separating the western edge of the Arabian Plate from Africa (Camp and Roobol, 1992).

Sultan et al. (1993) have indicated that the Arabian and Nubian sections of the shield have remained as rigid plates during the Red Sea rifting, and the site of the present Red Sea has probably a zone of structural weakness in the late Precambrian, with the breakup and rifting controlled by pre-existing fault systems (Makris and Rihm, 1991; Bosworth et al., 2005). A bathymetric and topographic map prepared from various sources is presented in Fig. 3. The sea is connected to the Arabian Sea and Indian Ocean via the Gulf of Aden in the south through the narrow Strait of Bab-al- 


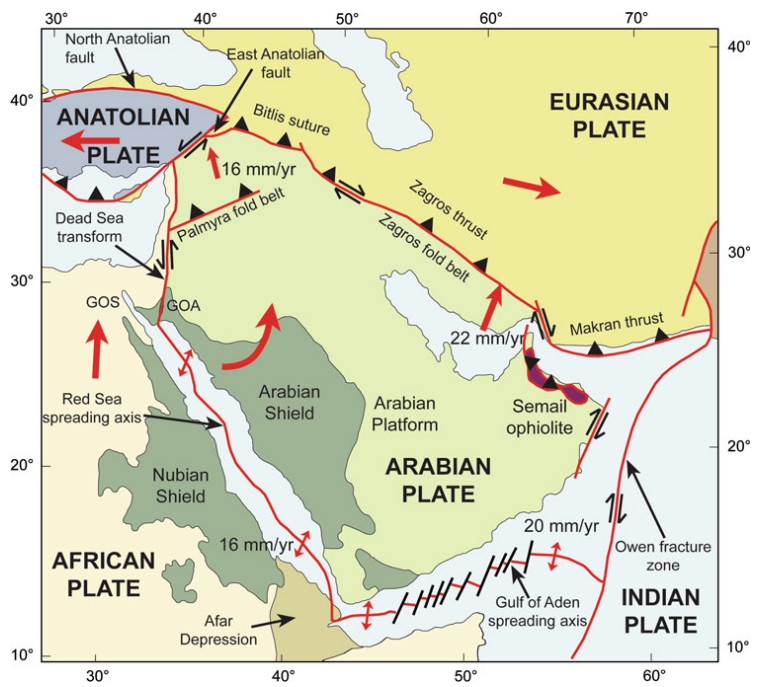

Fig. 2. Main tectonic features of the Arabian Peninsula and surrounding areas (modified after Stern and Johnson, 2010).

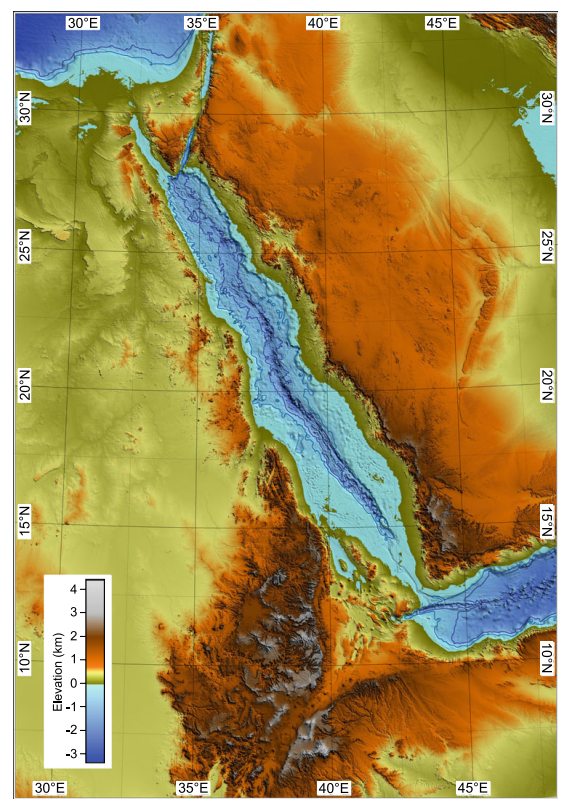

Fig. 3. Topography and bathymetric map. Bathymetric contours are at $500 \mathrm{~m}$ interval (Courtesy Marco Ligi). 
Mandab, which has a minimum with of only $30 \mathrm{~km}$, where the main channel is about $310 \mathrm{~m}$ deep and $25 \mathrm{~km}$ wide at Perim Island (Morcos, 1970).

Subduction Zone, and the Zagros Fold-Thrust Belt up to the East Anatolian Fault in the northwest. To the southeast, the Owen and Murray Fracture Zones separate the Arabian Plate from the Indian Plate (El-Hussain et al., 2018) (Fig. 4). The Red Sea has been opening since the Arabian plate broke away from the African plate about 24 million years ago (Bosworth et al., 2005). The rifting began with continental stretching and thinning and later progressed to sea-floor spreading. The rate of opening increases from about $7 \mathrm{~mm} /$ year in the northern Red Sea to roughly $16 \mathrm{~mm} /$ year in the south (ArRajehi et al., 2010; Reilinger et al., 2015). The present velocity of

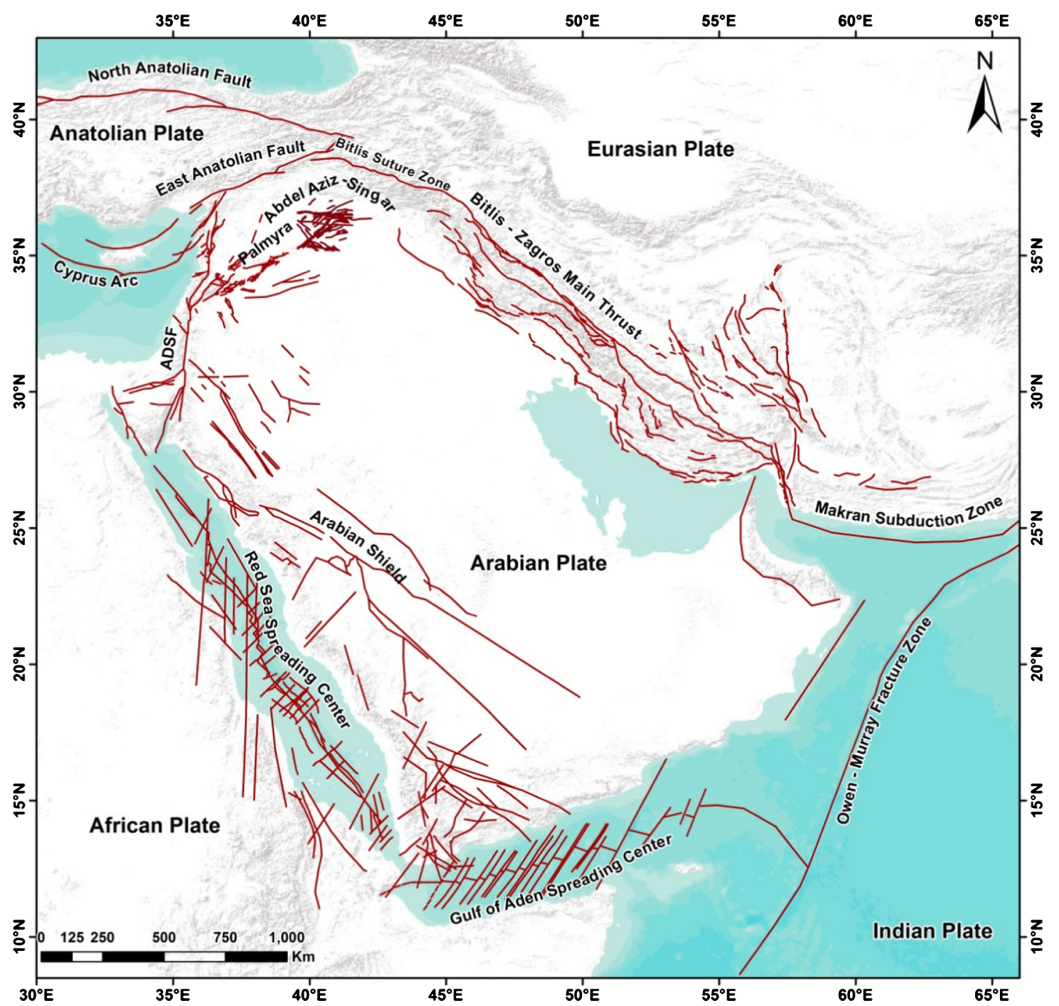

Fig. 4. Tectonic elements of the Arabian Plate (Deif et al., 2017). ADSF=Aqaba-Dead Sea Fault, compiled from Johnson (1998), Brew (2001), Brew et al. (2001), Gullen et al. (2002), Hessami et al. (2003), Bosworth et al. (2005), and Gomez et al. (2007). Brown lines indicate the faults. 
Arabia with respect to Eurasia increases from west to east along the Persian Gulf from 18 to $25 \mathrm{~mm}$ /year, oriented about N $10^{\circ} \mathrm{E}$ (Madahizadeh et al., 2016; Sella et al., 2002: Walpersdorf et al., 2006).

\section{Seismicity and Seismotectonic of Zagros}

The convergence between the Arabian plate in the southwest and Eurasia in the northeast led to the complete closure of the Neo-Tethys Ocean and the formation of the Zagros continental collision zone (Jackson and McKenzie, 1984).

The Zagros is the most seismically active region in Iranian plateau. More than $50 \%$ of Iranian earthquakes, recorded by global seismic networks, have occurred in the Zagros Range (Mirzaei, 1997). Most of the earthquakes located in the Zagros Simply Folded Belt have the reverse mechanism and occur at depths of less than $20 \mathrm{~km}$. Their rupture has also rarely reached the surface, which can be due to the presence of salt layers in the sedimentary cover (Jackson and Fitch, 1981; Talebian and Jackson, 2004). Earthquake focal mechanism solutions demonstrate shortening and thickening through major thrust faults, responsible for deformation in the Zagros (e.g., Mostafazadeh et al., 2000: Talebian and Jackson 2004). Although the seismicity is intensive in the Zagros, the contribution of seismic moments released by the earthquakes to the overall convergence is relatively low (Jackson and McKenzie, 1988; Vernant et al., 2004). A great number of earthquakes in highly seismic region of Zagros, occur on hidden faults. There is considerable uncertainty about their extent, geometry and the mechanism. most of Zagros seismicity is associated with the strike-slip faults rather than the thrust faults (e.g. Tatar et al., 2004). Talebian and Jackson (2004) and Yamini-Fard et al. (2006) are a few examples for doing investigations on Zagros seismotectonic province implicating the recent seismic activity within this area (Nemati, 2015).

\section{Seismicity and seismotectonics of the Red Sea}

Previous seismological studies in the Red Sea region have indicated the presence of a rather moderate-low shallow seismicity. The concentration of 
seismicity and active volcanism along the axial trough has long been mentioned to show the present-day continuous rifting (Drake and Girdler, 1964; Fairhead and Girdler, 1970, 1972).

El-Isa and Al-Shanti (1989) concluded that the central distribution of historical and instrumental data and their characteristics illustrate a general correlation with regional geology and tectonics. Their studies have shown that $\sim 60 \%$ of all energy released from instrumental earthquakes has been released from concentrated earthquakes in the spreading zone. These three sequences occurred at the intersection of three major structural trends, the Gulf of Aqaba-Dead Sea Rift, the Gulf of Suez, and the main Red Sea rift. The Red Sea is divided into three distinct zones; each zone represents different stages of development (Cochran and Martinez, 1988). The most recent earthquake sequences occurred in 1969, 1972, and 2001. The 1969 Shadwan sequence, characterized by a maximum magnitude mb 6.0 and $\mathrm{Ms}$ 6.8 , occurred in the north near Shadwan. The largest event of moment magnitude $(\mathrm{Mw}) 7.1$ took place on 22 November 1995 at the Gulf of Aqaba, causing structural damage to buildings in several cities along the gulf coast (Al-Tarazi, 2000).

Most of the seismicity in this area is of earthquake swarm and is related to subsurface volcanic activities. Fig. 5 shows the locations of instrumental earthquakes in and around the Arabian Peninsula up to 2015 for earthquakes with magnitude above $\mathrm{Mw}=3.5$. Most of earthquake epicenters are concentrated along the plate boundary, in addition to scattered seismic activity within the Arabian Shield.

It is found that 88 earthquakes occurred in the study area during the period 627-1955. These include only two $\mathrm{M}=7$, three 6.8 , and two 6.6 earthquakes, the remaining are of $\mathrm{M} \leq 6.4$. Most of these have occurred in the form of sequences and swarms and many are volcanic related (El-Isa, 2015). Since April 14, 2009, and more than three months in sequence, an earthquake swarm has occurred in Lunayyir in Saudi Arabia sheild, along $\sim 50$ kilometers of the Red Sea coast.

Most investigators have pointed out that the seismicity of the northern Red Sea is lower than that of the southern part (e.g., Pedone et al., 1992; Al-Amri, 1995a,b; Daggett et al., 1986); others, however, have referred to an apparent lower seismicity in the northern part, e.g., El-Isa and Al-Shanti (1989). 


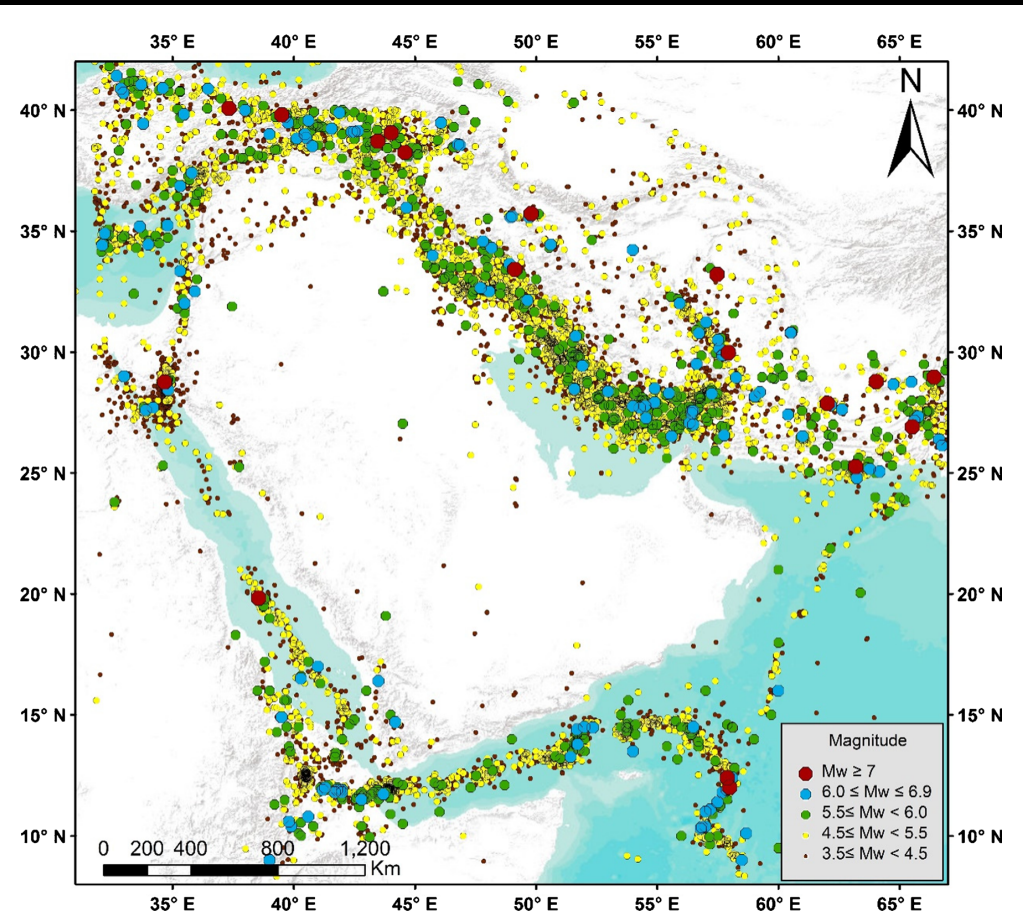

Fig. 5. Instrumental recorded earthquakes of the Arabian Plate from 1900 to 2015 (Deif et al., 2017).

\section{Research Method}

In this study, IRSC, ISC, USGS / NEIC and CMT data were used to prepare earthquake catalogues. The data period used is 1900 to 2019. Variables investigated in this study include time, location, frequency, focal mechanism, and depth of earthquakes. The software used is Matlab, GMT and Isola. Figs. 6-7 show the seismicity map of the two study areas.

\subsection{Depth of earthquakes in two areas of Zagros and Red Sea}

The decrease of the compressive force in Zagros shortens this zone along the northeast-southwest. This shortening at the surface shows the folding of the sediments and the upper part of the crystalline crust displays reversed faults. According to Engdahl et al. (2006) and Maggi et al. (2000), the focal depth of most of the earthquakes in the Zagros region occurred at a depth 


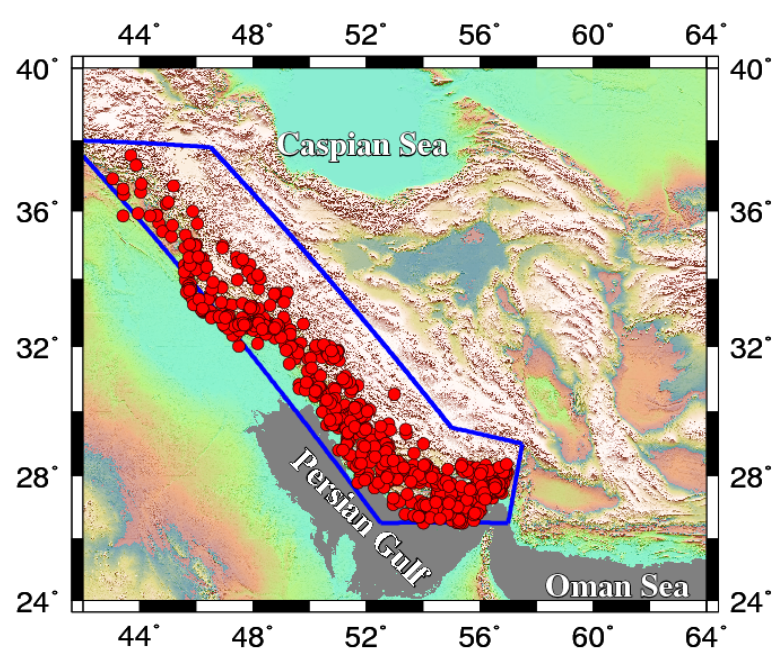

Fig. 6. Seismicity map for earthquakes with a magnitude greater than 5 in the Zagros region (1900 to 2019).

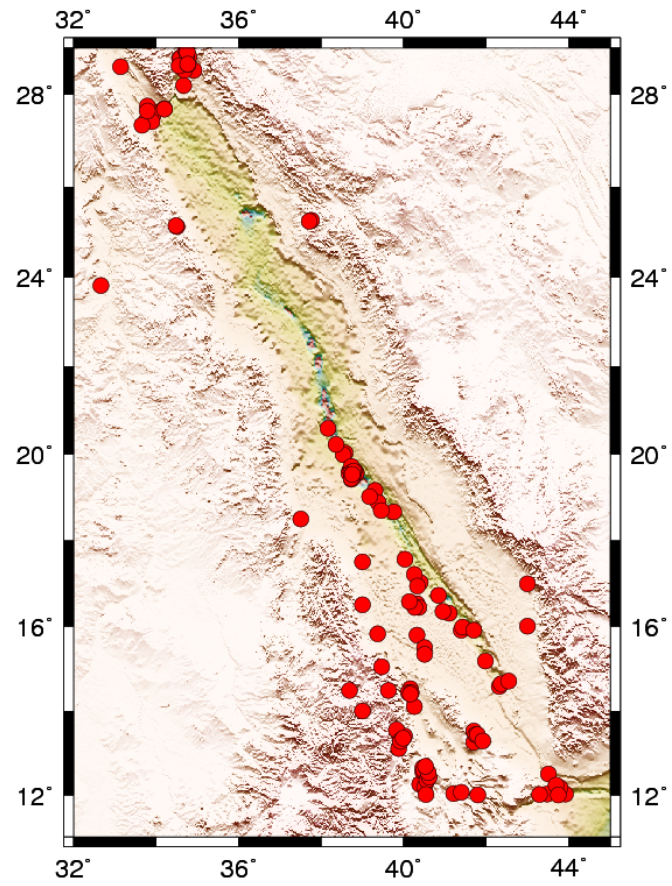

Fig. 7. Seismicity map for earthquakes with a magnitude greater than 5 in the Red Sea region (1900 to 2019). 
range of about $10-15 \mathrm{~km}$. In their review of waveform-modelled depths in the Zagros, Talebian and Jackson (2004) found no earthquakes deeper than $20 \mathrm{~km}$ anywhere except near the Oman Line in the extreme SE Zagros. The mean depth of events indicates the accumulation of earthquakes in the upper part of the basement under sedimentary cover. Earthquake depth distribution in the Zagros region based on Engdahl et al. (2006) is shown in Fig. 8.

\section{Zagros Events}

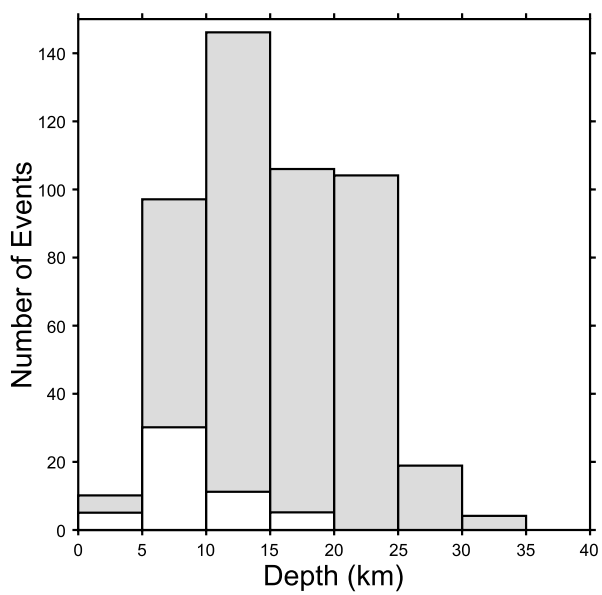

Fig. 8. Earthquake depth distribution in the Zagros region (depths determined by waveform modelling are not shaded) (Engdahl et al., 2006).

In this study, the frequency of the Zagros earthquakes is much higher (approximately 5.5 times) that of the Red Sea. The maximum depth of earthquakes in Zagros is greater than the Red Sea, indicating that the Zagros Crust is thicker than the Red Sea, which may be due to different tectonic features. Depth of diagrams of the Zagros and the Red Sea earthquakes in this study are shown in Figs. 9-10.

\subsection{Removing dependent events from the used ISC Catalogue}

In order to assess the seismicity parameters, we eliminated the dependent events (i.e. the aftershocks), which are associated with large fluctuations of seismic activity in space and time. For this purpose the catalogues were declustered using Gardner and Knopoff (1974)'s method. 


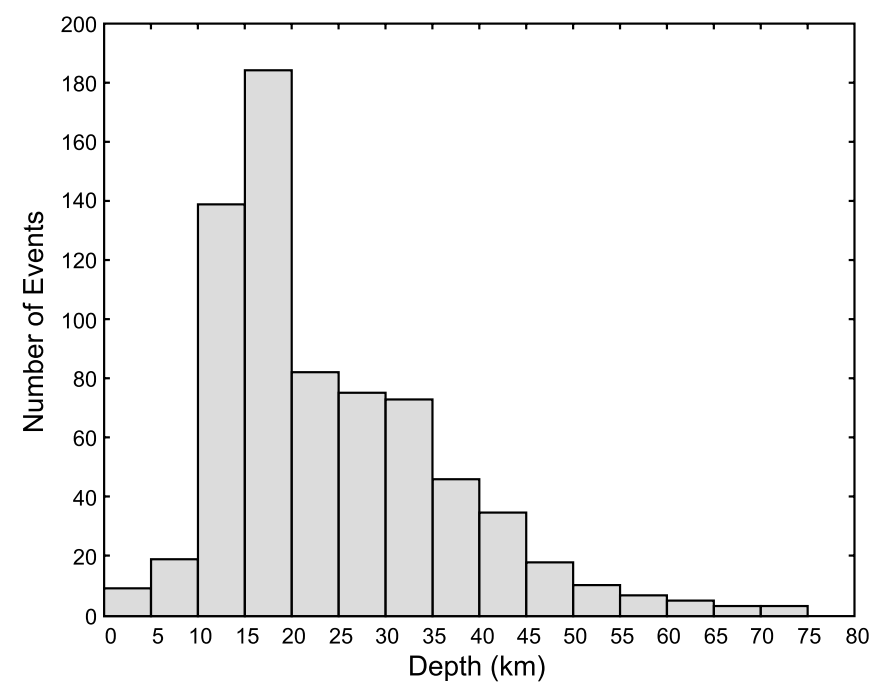

Fig. 9. Depth diagram of the Zagros earthquakes (from 1900 to 2019).

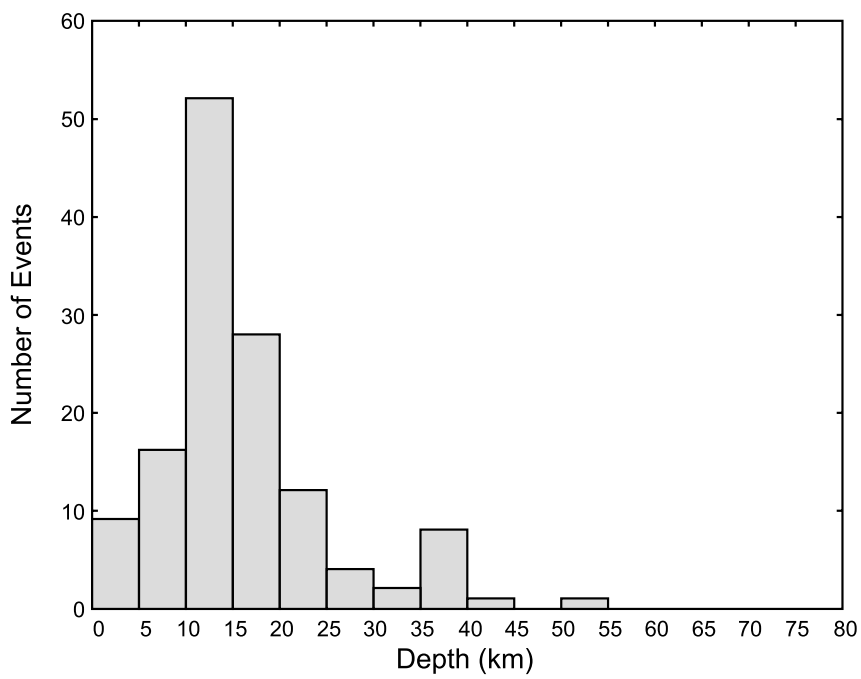

Fig. 10. Depth diagram of the Red Sea earthquakes from (from 1900 to 2019).

In this method, the intervals between events in time and space are used as the criteria for filtering data, which is defined by the magnitude of the main earthquake. In other words, in order to remove dependent events in a series of earthquakes (including main shock and dependent earthquakes 
the nearest earthquakes (in terms of time intervals and position) that are commensurate with the magnitudes of the major earthquakes are known as dependent data and are filtered. In the present study, foreshocks and aftershocks were removed from the catalogue using ZMAP software (Wiemer, 2001). The number of earthquakes in the initial catalogue was 842 earthquakes with $\mathrm{Mw} \geq 5$, which decreased to 454 after the declustering process (i.e. $\sim 46 \%$ of events were filtered from the raw catalogue). In this study, the regional dataset of the International Seismological Centre (ISC) is applied. This catalogue is available at http://www.isc.ac.uk/. Time window and location of removed aftershocks and foreshocks using ZMAP software according to Gardner and Knopoff (1974)'s method is shown in Fig. 11.
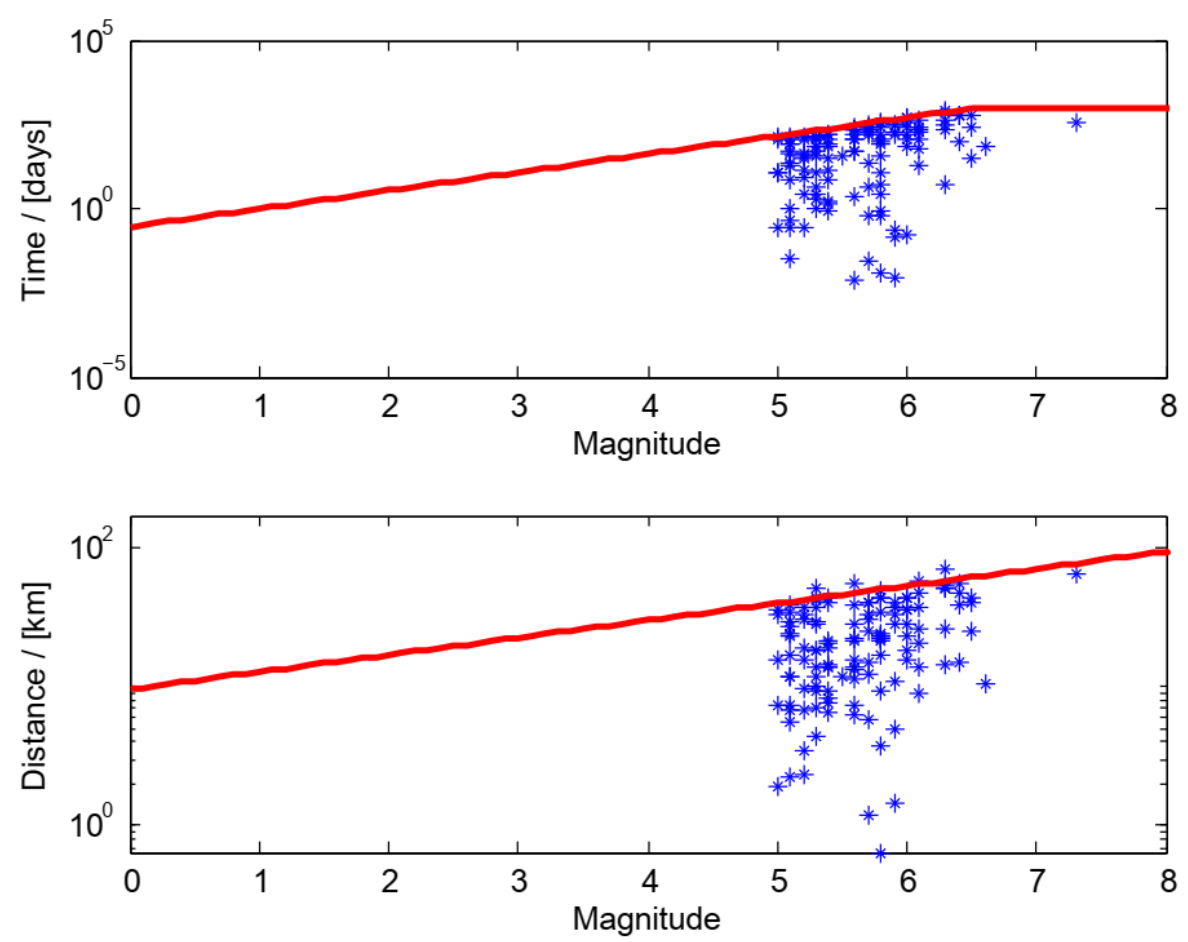

Fig. 11. Time window (top) and location (bottom) of removed aftershocks and foreshocks using ZMAP software. Aftershocks identification windows in time and space domains (red lines in upper and lower panels, respectively) according to Gardner and Knopoff (1974)'s method, as implemented in ZMAP 6.0. Stars show the data within 126 revealed clusters of earthquakes. 


\subsection{Estimation of seismicity parameters of Zagros and Read Sea}

The Gutenberg-Richter relation (Gutenberg and Richter, 1944) is one of the well known empirical relations in seismology. It presents the frequency of occurrence of earthquakes as a function of magnitude (Eq. 1):

$\log _{10} N=a-b M$,

where $N$ is the cumulative number of earthquakes with magnitude greater than $M, a$-value and $b$-value are constants to be determined. The $a$-value is related to the seismic activity and $b$ value is the slope of frequencymagnitude distribution and reveals the ratio of number of smaller to larger earthquakes (Gutenberg and Richter, 1954; Ashtari Jafari, 2008).

In order to estimate the seismicity parameters of the two studied areas, the maximum likelihood method $(A k i, 1965)$ was used, as implemented in software package ZMAP 6.0 (Wiemer, 2001).

\subsubsection{Seismicity coefficients for the studied regions}

The values obtained for $a$ and $b$ parameters are presented in Table 1 . Figs. 12-13 show the results for the Zagros and the Red Sea seismicity, respectively. The results indicate that the $b$-value for the two regions is approximately the same. As the ratio of small to large earthquakes is almost the same, however, the total number of earthquakes in Zagros is much higher and a value also confirms this claim.

Table 1. The values of Gutenberg-Richter parameters for Zagros and Red Sea regions.

\begin{tabular}{|c|c|c|c|}
\hline Region & $\mathbf{a}$ & $\mathbf{b}$ & Mc \\
\hline Zagros & 8.49 & $1.19 \pm 0.06$ & 5.0 \\
\hline Red Sea & 7.27 & $1.11 \pm 0.2$ & 5.2 \\
\hline
\end{tabular}

\subsection{Earthquakes focal mechanism estimation for the two studied regions}

Examination of the focal mechanism obtained from the CMT references indicates that most of the earthquakes in the Zagros zone are of the reverse type and for the Red Sea are of the normal type, which Figs. 14-15 illustrate this well. In these figures, three different colors of yellow (up to $20 \mathrm{~km}$ ), 


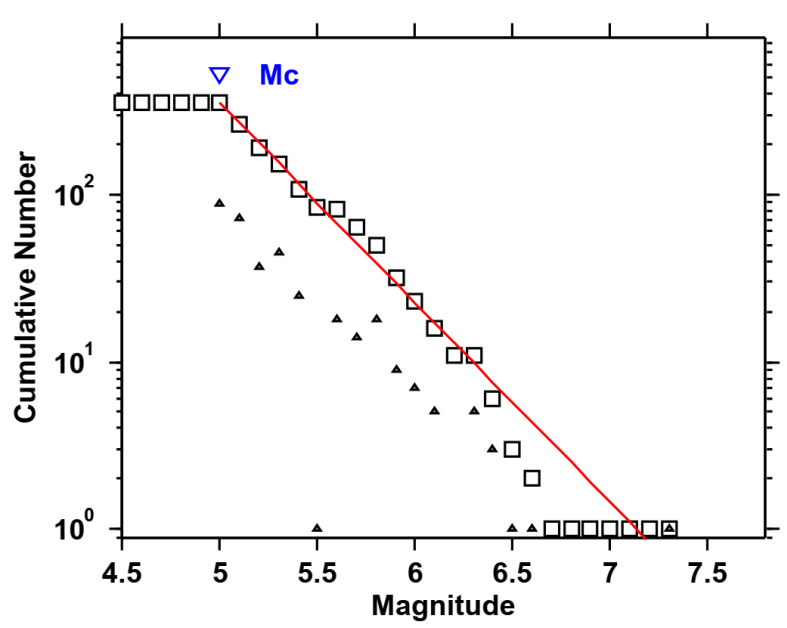

Fig. 12. Magnitude-frequency (Gutenberg-Richter) distribution for instrumental earthquakes in the Zagros region.

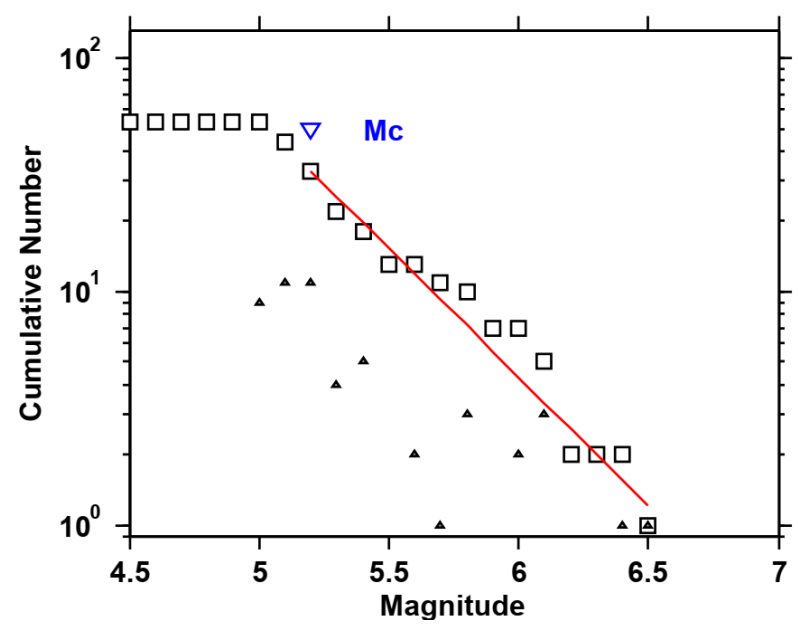

Fig. 13. Magnitude-frequency (Gutenberg-Richter) distribution for instrumental earthquakes in the Red Sea region.

blue (up to $40 \mathrm{~km}$ ), and red (greater than $40 \mathrm{~km}$ ) are used to separate the focal depths of the earthquakes, respectively. The Zagros and Red Sea earthquakes occur to depths of about $20 \mathrm{~km}$ (marked in yellow). In the Zagros region, there are more red and blue focal mechanism ones. As mentioned 


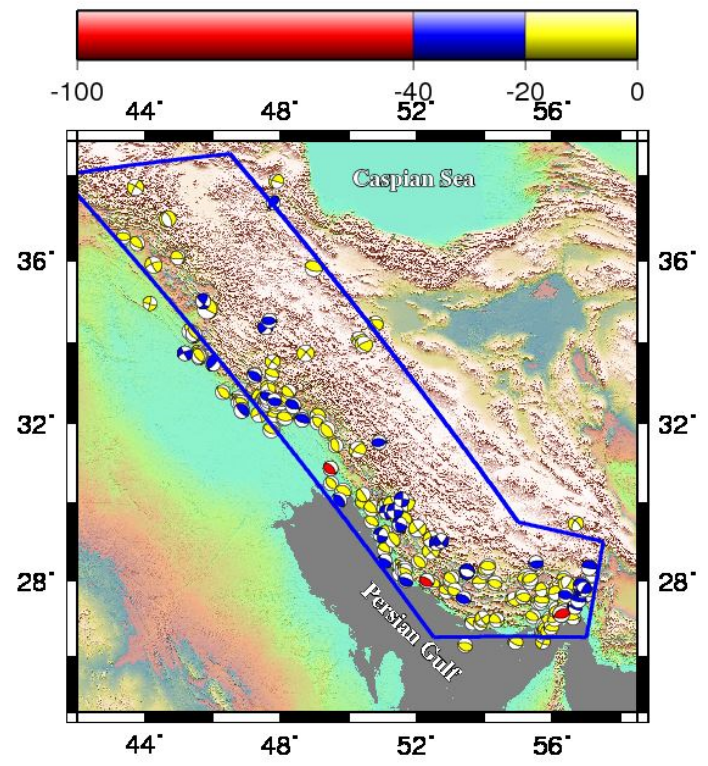

Fig. 14. Focal mechanism of earthquakes larger than magnitude 5 in the Zagros region (ranging from 1900 to 2019).

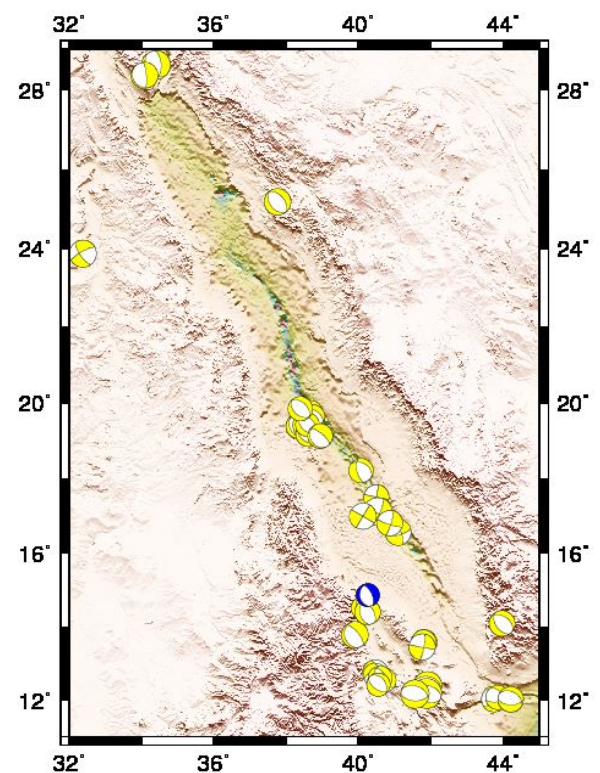

Fig. 15. Focal mechanism of earthquakes larger than magnitude 5 in the Zagros region (ranging from 1900 to 2019). 
earlier, the depth of the earthquakes in the Zagros area is greater than that of the Red sea region. That is, earthquakes occur with high frequency but with relatively low magnitudes.

Waveform modelling using Isola software by Zahradnik et al. (2005) has been extended to local and regional intervals using full-function Green's function calculation with discrete wave number method (Bouchon, 1981). For a number of earthquakes whose focal mechanism was not present in the above catalogue, the focal mechanisms of these earthquakes have been obtained by modelling waveforms using Isola software (Zahradnik et al., 2005) and shown in Table 2.

Table 2. Focal mechanism of five earthquakes larger than 5 obtained with Isola software.

\begin{tabular}{|c|c|c|c|c|c|c|c|c|c|c|c|c|c|c|c|c|c|}
\hline \multirow[b]{2}{*}{$\mathrm{YY} / \mathrm{MM} / \mathrm{DD}$} & \multirow[b]{2}{*}{$\mathrm{H} / \mathrm{M} / \mathrm{S}$} & \multirow[b]{2}{*}{ LAT } & \multirow[b]{2}{*}{ LON } & \multirow[b]{2}{*}{$\mathrm{M}_{\mathrm{L}}$} & \multirow[b]{2}{*}{$\mathrm{D}$} & \multirow[b]{2}{*}{$\mathrm{S} 1$} & \multirow[b]{2}{*}{ D1 } & \multirow[b]{2}{*}{$\mathrm{R} 1$} & \multirow[b]{2}{*}{$\mathrm{S} 2$} & \multirow[b]{2}{*}{ D2 } & \multirow[b]{2}{*}{$\mathrm{R} 2$} & \multirow[b]{2}{*}{ Mo } & \multicolumn{2}{|c|}{$\mathrm{P}$} & \multicolumn{2}{|c|}{$\mathrm{T}$} & \\
\hline & & & & & & & & & & & & & 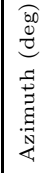 & 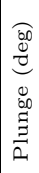 & 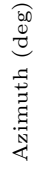 & 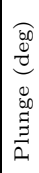 & \\
\hline $08 / 09 / 26$ & $15 / 52 / 24$ & 27.62 & 56.43 & 5.1 & 31 & 51 & 75 & 168 & 143 & 79 & 14 & $1.846 \mathrm{E}+16$ & 277 & 3 & 7 & 19 & \\
\hline $09 / 10 / 04$ & $21 / 50 / 49$ & 31.82 & 49.5 & 5.1 & 15 & 131 & 80 & 78 & 0 & 14 & 138 & $3.916 \mathrm{E}+16$ & 230 & 35 & 27 & 54 & \\
\hline $10 / 01 / 16$ & $20 / 23 / 38$ & 32.55 & 48.40 & 5 & 18 & 112 & 47 & 92 & 289 & 42 & 87 & $1.987 \mathrm{E}+16$ & 201 & 3 & 56 & 88 & \\
\hline $10 / 05 / 14$ & $18 / 49 / 56$ & 29.41 & 51.46 & 5.3 & 15 & 20 & 29 & 158 & 129 & 79 & 62 & $1.813 \mathrm{E}+16$ & 241 & 30 & 10 & 49 & \\
\hline $13 / 05 / 23$ & $22 / 44 / 56$ & 27.22 & 53.58 & 5.1 & 18 & 322 & 35 & -70 & 119 & 56 & -103 & $1.769 \mathrm{E}+16$ & 351 & 75 & 218 & 11 & \\
\hline
\end{tabular}

YY/MM/DD: Year/Month/Day, H/M/S: Hour,Minute,Second, LAT $\left({ }^{\circ}\right.$ E): Latitude, LON $\left({ }^{\circ} \mathrm{N}\right)$ : Longitude, $\mathrm{M}_{\mathrm{L}}$ : Local Magnitude, D (km): Depth, S1 (deg): Strike1, D1 (deg): Deep1, R1 (deg): Rake1, S2 (deg): Strike2, D2 (deg): Deep2, R2 (deg): Rake2, M0 (N.m): seismic moment, P: Pression axis, T: Tension axis

\section{Conclusions}

The Red Sea and Zagros are both seismically active areas of the world. The Red Sea earthquakes are a type of sea-floor spreading and its earthquakes occur at depths corresponded to an oceanic crust, while the Zagros earthquakes are caused by the collision of two continental crusts. The present study compares seismicity and tectonic features of these areas by analyzing seismicity data. The Gutenberg Richter relationship shows that the $a$-value in the Zagros is 8.49 and in the Red Sea is 7.27 , that is the Zagros seis- 
micity rate is about 5.5 times higher than the Red Sea. However, their $b$-value does not differ much from each other and it means that there is no difference in the ratio of large to small earthquakes in these two areas. On the one hand, there is a relative difference between the focal depths of the events in these two regions; the highest frequency of the Zagros earthquakes is approximately $15-20 \mathrm{~km}$ in depth and is approximately $10-15 \mathrm{~km}$ for the Red Sea. The mechanism of the Zagros earthquakes is due to the pressure of the Arabian plate moving northeastward, in the form of reverse faulting or thrust fault with high dip. It is seen along the faults of the region. Most of the Zagros faults are oriented perpendicular to the compression direction (convergence) of the Arabian plate. Unlike the Zagros, the main mechanism of earthquakes in the northern part of the Red Sea is normal and its southern part includes strike-slip component. Geodynamic studies also show that convergence rates are high in the Zagros region and it seems that due to this high velocity there is no opportunity for stress accumulation and large earthquakes in this area. That is, earthquakes occur with high frequency but with relatively low magnitudes.

\section{References}

Aki K., 1965: Maximum likelihood estimate of $b$ in the formula $\log N=a-b M$ and its confidence limits. Bull. Earthq Res. Inst. Univ. Tokyo, 43, 237-239.

Al-Amri A. M., 1995a: Preliminary seismic hazard assessment of southern Red Sea region. Eur. Earthq. Eng., 3, 33-38.

Al-Amri A. M., 1995b: Recent seismic activity in the northern Red Sea. J. Geodyn., 20, 3, 243-253, doi: 10.1016/0264-3707(95)00007-V.

Alavi M., 1994: Tectonics of the Zagros orogenic belt of Iran: new data and interpretations. Tectonophysics, 229, 3-4, 211-238, doi : 10.1016/0040-1951(94)90030-2.

Alavi M., 2004: Regional stratigraphy of the Zagros fold-thrust belt of Iran and its proforeland evolution. Am. J. Sci., 304, 1, 1-20, doi: 10.2475/ajs.304.1.1.

Alavi M., 2007: Structures of the Zagros fold-thrust belt in Iran. Am. J. Sci., 307, 9, 1064-1095, doi: 10.2475/09.2007.02.

Allahyari K., Saccani E., Pourmoafi M., Beccaluva L., Masoudi F., 2010: Petrology of mantle peridotites and intrusive mafic rocks from the Kermanshah ophiolitic complex (Zagros belt, Iran):implications for the geodynamic evolution of the neoTethyan oceanic branch between Arabia and Iran. Ofioliti, 35, 2, 71-90.

Al-Tarazi E., 2000: The Major Gulf of the Aqaba Earthquake, 22 November 1995 - Maximum Intensity Distribution. Nat. Hazards, 22, 1, 17-27, doi : 10.1023/A : 10081098 10031. 
ArRajehi A., McClusky S., Reilinger R., Daoud M., Alchalbi A., Ergintav S., Gomez F., Sholan J., Bou-Rabee F., Ogubazghi G., Haileab B., Fisseha S., Asfaw L., Mahmoud S., Rayan A., Bendik R., Kogan L., 2010: Geodetic constraints on present-day motion of the Arabian Plate: Implications for Red Sea and Gulf of Aden rifting. Tectonics, 29, 3, TC3011, doi: 10.1029/2009TC002482.

Ashtari Jafari M., 2008: The distribution of b-value in different seismic provinces of Iran. The 14th World Conference on Earthquake Engineering, Beijing, China, doi: 10.13 140/RG.2.1.4514.3523.

Berberian M., 1995: Master "blind" thrust faults hidden under the Zagros folds: active basement tectonics and surface morphotectonics. Tectonophysics, 241, 3-4, 193224, doi: 10.1016/0040-1951(94)00185-C.

Besse J., Torcq F., Gallet Y., Ricou L. E., Krystyn L., Saidi A., 1998: Late Permian to late Triassic paleomagnetic data from Iran: constraints on the migration of the Iranian block through the Tethyn ocean and initial destruction of Pangaea. Geophys. J. Int., 135, 1, 77-92, doi: 10.1046/j.1365-246X.1998.00603.x.

Bosworth W., Huchon P., McClay K., 2005: The Red Sea and Gulf of Aden basins. J. Afr. Earth Sci., 43, 1, 334-378, doi: 10.1016/j.jafrearsci.2005.07.020.

Bouchon M., 1981: A simple method to calculate Green's functions for elastic layered media. Bull. Seismol. Soc. Am., 71, 4, 959-971.

Brew G. E., 2001: Tectonic evolution of Syria interpreted from integrated geophysical and geological analysis. PhD thesis, Cornell Univ., USA.

Brew G., Barazangi M., Al-Maleh A., Sawaf T., 2001: Tectonic and geologic evolution of Syria. GeoArabia 6, 4, 573-616.

Camp V. E., Roobol M. J., 1992: Upwelling asthenosphere beneath western Arabia and its regional implications. J. Geophys. Res., 97, B11, 15255-15271, doi: 10.1029/92JB 00943.

Cochran J. R., Martinez F., 1988: Evidence from the northern Red Sea on the transition from continental to oceanic rifting. Tectonophysics, 153, 1-4, 25-53, doi : 10.1016/ 0040-1951 (88) 90006-6.

Cochran J., Gaulier J. M., LePichon X., 1991: Crustal structure and the mechanism of extension in the Northern Red Sea: constraints from gravity anomalies. Tectonics, 10, 5, 1018-1037, doi: 10.1029/91TC00926.

Daggett P., Morgan P., Boulos F., Hennin S., El-Sherif A., El-Sayed A., Basta N., Melek Y., 1986: Seismicity and active tectonics of the Egyptian Red Sea margin and the northern Red Sea. Tectonophysics, 125, 4, 313-324, doi: 10.1016/0040-1951(86) 90168-X.

Dehghani G. A., Makris J., 1984: The gravity field and crustal structure of Iran. Neues Jahrb. Geol. Paläontol. Abh., 168, 2-3, 215-229, doi: 10.1127/njgpa/168/1984/ 215.

Deif A., Al-Shijbi Y., El-Hussain I., Ezzelarab M., Mohamed A. M. E., 2017: Compiling an earthquake catalogue for the Arabian Plate, Western Asia. Journal of Asian Earth Sciences, 147, 1, 345-357, doi: 10.1016/j.jseaes.2017.07.033. 
DeMets C., Gordon R. G., Argus D. F., Stein S., 1994: Effect of recent revisions to the geomagnetic reversal time scale on estimates of current plate motions. Geophys. Res. Lett., 21, 20, 2191-2194, doi: 10.1029/94GL02118.

Drake C. L., Girdler R. W., 1964: A geophysical study of the Red Sea. Geophys. J. Roy. Astron. Soc., 8, 5, 473-495, doi: 10.1111/j.1365-246X.1964.tb06303.x.

El-Hussain I., Al-Shijbi Y., Deif A., Mohamed A. M. E., Ezzelarab M., 2018: Developing a seismic source model for the Arabian Plate. Arab. J. Geosci., 11, 15, 435, doi: $10.1007 / \mathrm{s} 12517-018-3797-7$.

El-Isa Z. H., Al Shanti A., 1989: Seismicity and tectonics of the Red Sea and western Arabia. Geophys. J. Int., 97, 3, 449-457, doi: 10.1111/j.1365-246X.1989.tb00515.x.

El-Isa Z. H., 2015: Seismicity and seismotectonics of the Red Sea Region, Arab. J. Geosci., 8, 10, 8505-8525, doi: 10.1007/s12517-015-1819-2.

Engdahl E. R., Jackson J. A., Myers A. C., Bergman E. A., Priestley K., 2006: Relocation and assessment of seismicity in the Iran region. Geophys. J. Int., 167, 2, 761-778, doi: $10.1111 / \mathrm{j} .1365-246 \mathrm{X} .2006 .03127 . \mathrm{x}$.

Fairhead J. D., Girdler R. W., 1970: The seismicity of the Red Sea, Gulf of Aden and Afar triangle. Philos. Trans. Royal Soc. London, Ser. A, 267, 1181, 49-74.

Fairhead J. D., Girdler R. W., 1972: The seismicity of East African rift system. Tectonophysics, 15, 1-2, 115-122, doi : 10.1016/0040-1951(72)90056-X.

Falcon N. L., 1969: Problems of the relationship between surface structure and deep displacements illustrated by Zagros range. In: Kent P. E., Satterthwaite G. E., Spencer A. M. (Eds.): Time and Place in Orogeny. Geol. Soc., London, Spec. Publ., 3, 9-22, doi: 10.1144/GSL.SP.1969.003.01.02.

Gardner J. K., Knopoff L., 1974: Is the sequence of earthquakes in Southern California, with aftershocks removed, Poissonian? Bull. Seism. Soc. Am., 64, 5, 1363-1367.

Garfunkel Z., 1981: Internal structure of the Dead Sea leaky transform (rift) in relation to plate kinematics. Tectonophysics, 80, 1-4, 81-108, doi : 10.1016/0040-1951(81) 90 143-8.

Ghasemi A., Talbot C. J., 2006: A new tectonic scenario for the Sanandaj-Sirjan Zone (Iran). J. Asian Earth Sci., 26, 6, 683-693, doi: 10.1016/j.jseaes.2005.01.003.

Giese P., Makris J., Akashe B., Röwer P., Letz H., Mostaanpour M., 1984: The crustal structure in Southern Iran derived from seismic explosion data. Neues Jahrb. Geol. Paläontol. Abh., 168, 2-3, 230-243, doi: 10.1127/njgpa/168/1984/230.

Gomez F., Karam G., Khawlie M., McClusky S., Vernant P., Reilinger R., Jaafar R., Tabet C., Khair K., Barazangi M., 2007: Global Positioning System measurements of strain accumulation and slip transfer through the restraining bend along the Dead Sea fault system in Lebanon. Geophys. J. Int., 168, 3, 1021-1028, doi: 10.1111/j.1365-246X.2006.03328.x.

Guennoc P., Pautot G., Leqentrec M. F., Coutelle A., 1990: Structure of an early oceanic rift in the northern Red-Sea. Oceanol. Acta, 13, 2, 145-157.

Güllen L., Pinar A., Kalafat D., Özel N., Horasan G., Yilmazer M., Işikara A., 2002: Surface fault breaks, aftershock distribution, and rupture process of the 17 August 1999, Izmit earthquakes. Bull. Seismol. Soc. Am., 92, 1, 230-244, doi : 10.1785/012 0000815. 
Gutenberg B., Richter C. F., 1944: Frequency of earthquakes in California. Bull. Seismol. Soc. Am., 34, 4, 185-188.

Gutenberg B., Richter C. F., 1954: Seismicity of the Earth and Associated Phenomena. Princeton University Press, Princeton, N.J., USA.

Hessami K., Jamali F., Tabassi H., 2003: Major active faults in Iran. Ministry of Science, research and technology, International Institute of Earthquake Engineering and Seismology (IIEES), Tehran, Iran, 1:2,500,000 scale map.

Hatzfeld D., Tatar M., Priestley K., Ghafory-Ashtiany M., 2003: Seismological constraints on the crustal structure beneath the Zagros Mountain belt (Iran). Geophys. J. Int., 155, 2, 403-410, doi : 10.1046/j.1365-246X.2003.02045.x.

Head S. M., 1987: Red Sea fisheries - Chapter 17. In: Edwards A. J., Head S. M. (Eds.): Red Sea, Key Environment Series. Pergamon Press, Oxford, 363-382, doi : 10.1016 /B978-0-08-028873-4.50022-0.

Horton B. K., Hassanzadeh J., Stockli D. F., Axen G. J., Gillis R. J., Guest B., Amini A., Fakhari M. D., Zamanzadeh S. M., Grove M., 2008: Detrital zircon provenance of Neoproterozoic to Cenozoic deposits in Iran: implications for chronostratigraphy and collisional tectonics. Tectonophysics, 451, 1-4, 97-122, doi: 10.1016/j . tecto. 2007.11 .063$.

Jackson J. A., Fitch T. J., 1981: Basement faulting and the focal depth of the larger earthquakes in the Zagros mountains (Iran). Geophys. J. Roy. Astron. Soc., 64, 3, 561-586, doi: 10.1111/j.1365-246X.1981.tb02685.x.

Jackson J. A., McKenzie D. P., 1984: Active tectonics of the Alpine-Himalayan belt between Western Turkey and Pakistan. Geophys. J. Roy. Astron. Soc., 77, 1, 185264, doi: 10.1111/j.1365-246X.1984.tb01931.x.

Jackson J. A., McKenzie D. P., 1988: The relationship between plate motions and seismic moment tensors, and the rates of active deformation in the Mediteranian and the Middle East. Geophys. J. Roy. Astron. Soc., 93, 1, 45-73, doi : 10.1111/j.1365-24 6X.1988.tb01387.X.

James G. A., Wynd J. G., 1965: Stratigraphic Nomenclature of Iranian Oil Consortium Agreement Area. AAPG Bull., 49, 12, 2182-2245.

Johnson P. R., 1998: Tectonic map of Saudi Arabia and adjacent areas. Deputy Ministry for Mineral Resources, USGS TR-98-3, Saudi Arabia.

Khadivi Sh., 2010: Tectonic evolution and growth of the Zagros Mountain Belt (Fars, Iran): constraints from magnetostratigraphy, sedimentology and low-temperature thermochronometry. Earth Sciences. PhD thesis, Université Pierre et Marie Curie - Paris VI.

Madahizadeh R., Mostafazadeh M., Ashkpour-Motlagh Sh., 2016: Earthquake Potential in the Zagros region (Iran). Acta Geophys., De Gruyter, 64, 5, 1462-1494, doi: 10.1515/acgeo-2016-0080.

Maggi A., Jackson J. A., Priestley K., Baker C., 2000: A re-assessment of focal depth distributions in southern Iran, the Tien Shan and northern India: do earthquakes really occur in the continental mantle? Geophys. J. Int., 143, 3, 629-661, doi: 10.1046/j. $1365--246 x .2000 .00254 . x$. 
Makris J., Rihm R., 1991: Shear-controlled evolution of the Red Sea: pull apart model. Tectonophysics, 198, 2-4, 441-466, doi : 10.1016/0040-1951(91) 90166-P.

McQuarrie N., Stock J. M., Verdel C., Wernicke B. P., 2003: Cenozoic evolution of the Neotethys and implications for the causes of plate motions, Geophys. Res. Lett., 30, 2036, doi: 10.1029/2003GL017992.

Mirzaei N., 1997: Seismic zoning of Iran. Dissertation, Institute of Geophysics. State Seismological Bureau, Beijng, People's Republic of China, 134 p.

Mirzaei N., Gao M., Chen Y. T., 1998: Seismic source regionalization for seismic zoning of Iran: major seismotectonic provinces. J. Earthq. Pred. Res., 7, 4, 465-495.

Morcos S. A., 1970: Physical and chemical oceanography of the Red Sea. Oceanogr. Mar. Biol. Ann. Rev., 8, 73-202.

Mostafazadeh M., Alptekin O., Oncel A. O., 2000: Body waveform modeling of five moderately earthquakes in the Zagros fold thrust belt. JSEE (J. Seis. Earthq. Eng.). $\mathbf{2}, 3,1-10$.

Nemati M., 2015: Aftershocks investigation of 2010 Dec. and 2011 Jan. Rigan earthquakes in the southern Kerman province, SE Iran. J. Tethys (Iran), 3, 2, 96-113.

Nowroozi A. A., 1971: Seismo-tectonics of the Persian plateau, eastern Turkey, Caucasus and Hindu-Kush regions. Bull. Seismol. Soc. Am., 61, 2, 317-341.

Palano M., Imprescia P., Agnon A., Gresta S., 2018: An improved evaluation of the seismic/geodetic deformation-rate ratio for the Zagros Fold-and-Thrust collisional belt. Geophys. J. Int., 213, 1, 194-209, doi: 10.1093/gji/ggx524.

Paul A., Kaviani A., Hatzfeld D., Vergne J., Mokhtari M., 2006: Seismological evidence for crustal scale thrusting in the Zagros mountain belt (Iran). Geophys. J. Int., 166, 1, 227-237, doi: 10.1111/j.1365-246X.2006.02920.x.

Paul A., Hatzfeld D., Kaviani A., Tatar M., Péquegnat C., 2010: Seismic imaging of the lithospheric structure of the Zagros mountain belt (Iran). Geol. Soc., London, Spec. Pub., 330, 5-18, doi: 10.1144/SP330.2.

Pedone R., Lombardo P., Diamntidis D., 1992: Seismotectonic regionalization of the Red Sea Area and its application to seismic risk analysis. Nat. Hazards, 5, 3, 233-247, doi: $10.1007 /$ BF00125229.

Rasul N. M. A., Stewart I. C. F., 2015: The Red Sea - The Formation, Morphology, Oceanography and Environment of a Young Ocean Basin. Springer Earth System Sciences.

Reilinger R., McClusky S., ArRajehi A., 2015: Geodetic constraints on the geodynamic evolution of the Red Sea. In: Rasul N. M. A., Stewart I. C. F. (Eds.): The Red Sea - The Formation, Morphology, Oceanography and Environment of a Young Ocean Basin. pp. 135-149, Springer Earth System Sciences, Springer, Berlin, Heidelberg, doi: $10.1007 / 978-3-662-45201-1 \_7$.

Roeser H. A., 1975: A detailed magnetic survey of the southern Red Sea. Geol. Jahrb., D13, 131-153.

Saccani E., Allahyari K., Beccaluva L., Bianchini G., 2013: Geochemistry and petrology of the Kermanshah ophiolites (Iran): Implication for the interaction between passive rifting, oceanic accretion, and OIB-type components in the Southern Neo-Tethys Ocean. Gondwana Res., 24, 1, 392-411, doi : 10.1016/j.gr.2012.10.009. 
Sella G. F., Dixon T. H., Mao A., 2002: REVEL: A model for recent plate velocities from space geodesy. J. Geophys. Res., 107, B4, 2081, doi: 10.1029/2000JB000033.

Smith G., McNeill L., Henstock I. J., Bull J., 2012: The structure and fault activity of the Makran accretionary prism. J. Geophys. Res., Solid Earth, 117, B07407, doi : 10.1029/2012JB009312.

Snyder D. B., Barazangi M., 1986: Deep crustal structure and flexure of the Arabian Plate beneath the Zagros collisional mountain belt as inferred from gravity observations. Tectonics, 5, 3, 361-373, doi: 10.1029/TC005i003p00361.

Stern R. J., Johnson P. R., 2010: Continental lithosphere of the Arabian Plate: a geologic, petrologic, and geophysical synthesis. Earth Sci. Rev., 101, 1-2, 29-67, doi: 10.1016/j. earscirev. 2010.01.002.

Stöcklin J., 1974: Possible Ancient Continental Margin in Iran. In: Burk C. A., Drake C. L. (Eds.): The Geology of Continental Margins. Springer, New York, 873-887, doi : 10.1007/978-3-662-01141-6_64.

Sultan M., Becker R., Arvidson R. E., Shore P., Stern R. J., El Alfy Z., Attia R. I., 1993: New constraints on Red Sea rifting from correlations of Arabian and Nubian Neoproterozoic outcrops. Tectonics, 12, 6, 1303-1319, doi: 10.1029/93TC00819.

Swartz D. H., Arden D. D., 1960: Geologic history of the Red Sea area. AAPG Bull., 44, 1621-1637.

Talebian M., Jackson J., 2004: A reappraisal of earthquake focal mechanisms and active shortening in the Zagros Mountains of Iran. Geophys. J. Int., 156, 3, 506-526, doi : $10.1111 / \mathrm{j} .1365-246 \mathrm{X} .2004 .02092 . \mathrm{x}$.

Tatar M., Hatzfeld D., Martinod J., Walpersdorf A., Ghafori-Ashtiany M., Chéry J., 2002: The present-day deformation of the central Zagros from GPS measurements. Geophys. Res. Lett., 29, 19, 33-1-33-4, doi : 10.1029/2002GL015427.

Tatar M., Hatzfeld D., Ghafori-Ashtiany M., 2004: Tectonics of the central Zagros (Iran) deduced from microearthquakes seismicity. Geophys. J. Int., 156, 2, 255-266, doi: $10.1111 / \mathrm{j} .1365-246 \mathrm{X} .2003 .02145 . \mathrm{x}$.

Vernant Ph., Nilforoushan F., Hatzfeld D., Abbassi M. R., Vigny C., Masson F., Nankali H., Martinod J., Ashtiani A., Bayer R., Tavakoli F., Chéry J., 2004: Present-day crustal deformation and plate kinematics in the Middle East constrained by GPS measurements in Iran and northern Oman. Geophys. J. Int., 157, 1, 381-398, doi: $10.1111 / \mathrm{j} .1365-246 \mathrm{X} .2004 .02222 . \mathrm{x}$.

Walpersdorf A., Hatzfeld D., Nankal, H., Tavakol F., Nilforoushan F., Tatar M., Vernant P., Chéry J., Masson F., 2006: Difference in the GPS deformation pattern of North and Central Zagros (Iran). Geophys. J. Int., 167, 3, 1077-1088, doi: 10.1111/j . 1365-246X. 2006.03147.x.

Wiemer S., 2001: A software package to analyze seismicity: ZMAP. Seismol. Res. Lett., 72, 3, 373-382, doi: 10.1785/gssrl.72.3.373.

Yamini-Fard F., Hatzfeld D., Tatar M., Mokhtari M., 2006: Microseismicity at the intersection between the Kazerun fault and the Main Recent Fault (Zagros-Iran). Geophys. J. Int., 166, 1, 186-196, doi: 10.1111/j.1365-246X.2006.02891.x. 
Zahradnik J., Serpetsidaki A., Sokos E., Tselentis G. A., 2005: Iterative deconvolution of regional waveforms and double-event interpretation of the 2003 Lefkada earthquake, Greece. Bull. Seismol. Soc. Am., 95, 1, 159-172, doi: 10.1785/0120040035. 